\title{
THE EFFECTS OF CLIMATE CHANGE ON RURAL LIVELIHOOD ECOSYSTEM
}

\author{
DR. PAVNESH KUMAR ${ }^{1} \&$ SIDDHARTHA GHOSH ${ }^{2}$ \\ ${ }^{\text {I}}$ Professor, Department of Management Sciences, Bihar University, Bihar, India \\ ${ }^{2}$ Ph.D. Research Scholar, Department of Management Sciences, Bihar University, Bihar, India
} \begin{abstract}
India is majorly a country having a bulk of its population living in rural areas with more than $2 / 3^{\text {rd }}$ of the population and 70 percent of the workforce located in rural areas. Rural economy constitutes a major chunk i.e. 46 percent of India's national income. Despite urbanization being on the rise, more than half of the country's people are likely to be living in rural areas even by 2050. Thus, the development and growth of India cannot be imagined without the rural economy being strengthened as it holds the key to India's overall development.

Traditionally in India, agriculture and allied activities have played a major role in the rural economy and employment generation. Apart from agriculture, livestock farming, production of traditional local handicrafts, and service industry like construction, carpentry,etc have been another major area of employment generation in the rural economy.

India, like most other countries of the world, is posed with immediate economic disruptions post-Corona outbreak. The situation in India is unique as it has the $2^{\text {nd }}$ largest population in the world with more than half of its workforce located in villages. With the exodus of labor from urban cities to their rural hometown, the need to reboot the economy is being gravely felt more than ever. But, apart from the immediate economic problems, there is a much larger picture that still hasn't caught the attention of many. The problem being that of Climate change and its probable impact on weather patterns.
\end{abstract}

India's agriculture is predominantly depended on natural rainfall for their irrigation and any change in patterns of rainfall, temperature, moisture will not only present a grave challenge to farmers but also become a point of concern for livestock farming as animals too are affected by climate change. Animal fodder production will be affected, newer diseases can be seen among them, and in certain cases, animals might become unsuitable for a particular region to be kept as livestock.

The other two remaining components of the rural economy, handicraft, and service will also be impacted because of the imbalance created in farming and allied sectors. Hence, any plan which is to be incorporated for the rural economy must keep environmental change in consideration to arrive on any policy which can be put into practice for a long time. This paper will try to find the probable effects of weather change over the rural economy, what safeguarding measures should we take, and will suggest some newer practices which we can adopt to prepare India's rural economy from the immediate and looming threats of the future.

KEYWORDS: Indian Economy, Rural Economy, Climate Change, Agriculture, Livestock Farming, JEL :- Q57, Q58

Received: Jun 09, 2020; Accepted: Jun 29, 2020; Published: Jul 27, 2020; Paper Id.: IJMPERDJUN2020483

\section{INTRODUCTION}

The term, "Climatic Change" was suggested by "World Meteorological Organization" (WMO) in the year 1966 to include all types of variations being observed in weather patterns for time-scales lengthier than ten years. During 
the 70s, the term "Climate Change" was popularized which focussed on activities of humans which were drastically changing the climate. The term was also included in the United Nations Framework Convention on Climate Change (UNFCCC) and Intergovernmental Panel on Climate Change (IPCC). The term is now extensively used as a description of changes in weather being witnessed from the past few decades and its potential to emerge as a major problem in the world by the year 2030 .

Climate change is frequently used to denoteprecisely towards human activities, the bad effects of which have accumulated over time to cause irreversible changes in weather patternswhich have caused surface temperature of the earth to increase bringing "Global Warming". Earth's ecological balance is based on its atmosphere's temperature, which promotes evaporation from water bodies resulting in cloud formation and subsequent monsoons. From wind patterns to cyclic changes in weather, to migration of seasonal birds, all the flora and fauna is controlled by this delicate balance of nature. Any change in this whole system will likely produce catastrophic ripple effects and will change the face of the earth as we know it.

Many indications demonstrate human activities like the release of greenhouse gases which are heat-trapping in nature; from the usage of fossil fuels, rampant deforestation for urbanization, and changes in land-use patterns which are chiefly responsible for the observed changes in climate in the post-industrial revolution era. The high concentration of carbon dioxide gas is the largest contributing factor to global warming and has witnessed a rise by around 40 percent in the industrial era. This change has driven an increase in the earth's global surface temperatures and other associating changes in the weather are likely to be observed in the immediate future.

We require urgent actions to be taken so thatwe can adjust to the changing weather conditionsand to reduce its negative impacts and also for taking advantage of the new opportunities being presented by it. This will ensure that we adapt quickly. Another major response involves the efforts to decrease the expanse and swiftness of upcomingweather change by restraining emissions or eliminating carbon dioxide from our atmosphere. This response is known as mitigation. Adaptation and mitigation are connected in numerous ways and can be understood as strategiesthat are complementary. While future risks are reduced through efforts of mitigation, adaptation can diminish the results of changes that are already in motion as a consequence of earlier and current emissions.

\section{LITERATURE REVIEW}

Climate Change is a very wide topic. We will briefly discuss scientific findings and assumptions in this regard. The findings are a result of Meteorological data over the years analyzed and its immediate effects carefully simulated.

The World Bank, in its report "India: Climate Change Impacts" (Bank, 2020) states that India will experience extreme heat and will see uncommon and never seen before like bouts of hot weather which will happen frequently and will be covering large geographical areas. The warming will be around $4{ }^{\circ}$ Celsius mark which will force the western coast and the southern part of India to a higher temperature significantly impacting the agriculture in this region.

In the same report, it has also been mentioned that India will witness a change in the patterns of rainfall. While a decline in rainfall has been observed since the 1950s, the period has also seen events of heavy rainfall frequently. Even a 2 ${ }^{\circ}$ Celsius rise in temperature can make summer monsoons largely unpredictable. In the case of $4{ }^{\circ}$ Celsius warming, chances of having an extremely wet monsoon will increase ten-folds and will be seen once in every decade against the current trend of once in a century. 
The same report also predicts incidences of draughts becoming frequent in few parts of the country, specifically in the north-western region and also in the states of Jharkhand, Orissa, and Chattisgarh. Crop yields are expected to fall in this region significantly by 2040 . India, having the second largest population should be extremely concerned with projections of widespread droughts.

The same report also predicts a fall in the groundwater level which will happen mainly due to the overutilization of the same by the ever-increasing population. With more than 60 percent of India's agriculture currently depending upon agriculture, we must plan accordingly to prepare ourselves for such a scenario. The report also says that even without and climate change, 15 percent of the country's groundwater resources are being overexploited.

The same report predicts that most glaciers located in the Himalayan range are supplied moisture by summer monsoons and at $2.5^{\circ}$ Celsius of warming, glaciers will melt and the snow cover over the Himalayas will vanish. This will bring a death blow to the glacier-fed major rivers of India mainly Indus and Brahmaputra. Both the rivers will see an increased flow in spring and reduced flow in the summers. The river Ganga will be less affected since it will get water from predictable high annual rainfalls. Regardless of this, changes in the river flow patterns will greatly impact the irrigation system and will effects agriculture in the respective river basins.

The above-stated report also goes on to predict that India will witness a rise in seawater levels which will affect major cities located in the coastal areas e.g. Mumbai. It will also give way to rapid storms and will degrade the groundwater quality impacting agriculture and increasing outbreaks of diseases like cholera and diarrhea since saline water is favorable for bacterial growth.

All the above stated potential problems of the future are likely to provide a challenge for agricultural production and food security of individuals, water security, health concerns, energy production and can cause mass migration of the population and even conflicts in certain cases.

The aforementioned problems are not just environmental but will result in a bouquet of problems like widespread poverty, rampant economic inequality, concerns of public health and disruption in urban areas. It can also give rise to international water disputes with neighboring countries we share our rivers with e.g. China, Pakistan, and Bangladesh and can provide prospects of regional conflicts and cross border mass migration (Council, 2009, pp. 9-12)

\section{OBJECTIVES OF THE STUDY}

- To analyze the current effects of climatic change in India

- $\quad$ To understand the future implications of it.

- To analyze the predicted climatic changes with its perceived effect on India's rural livelihood

- To give suggestions as to what can be done to mitigate the risk of climate change.

\section{RESEARCH METHODOLOGY}

This study is based on secondary sources of information from various research publications, published newspapers, journals-online \& printed, magazines and websites, Information has been collected from libraries and websites. The literature is cross-checked and validated to gives the latest information. 


\section{TRENDS OF CLIMATE CHANGE IN INDIA - AGRICULTURAL PERSPECTIVE}

Below are the trends in rainfall and temperature measured over the past four and a half decades.

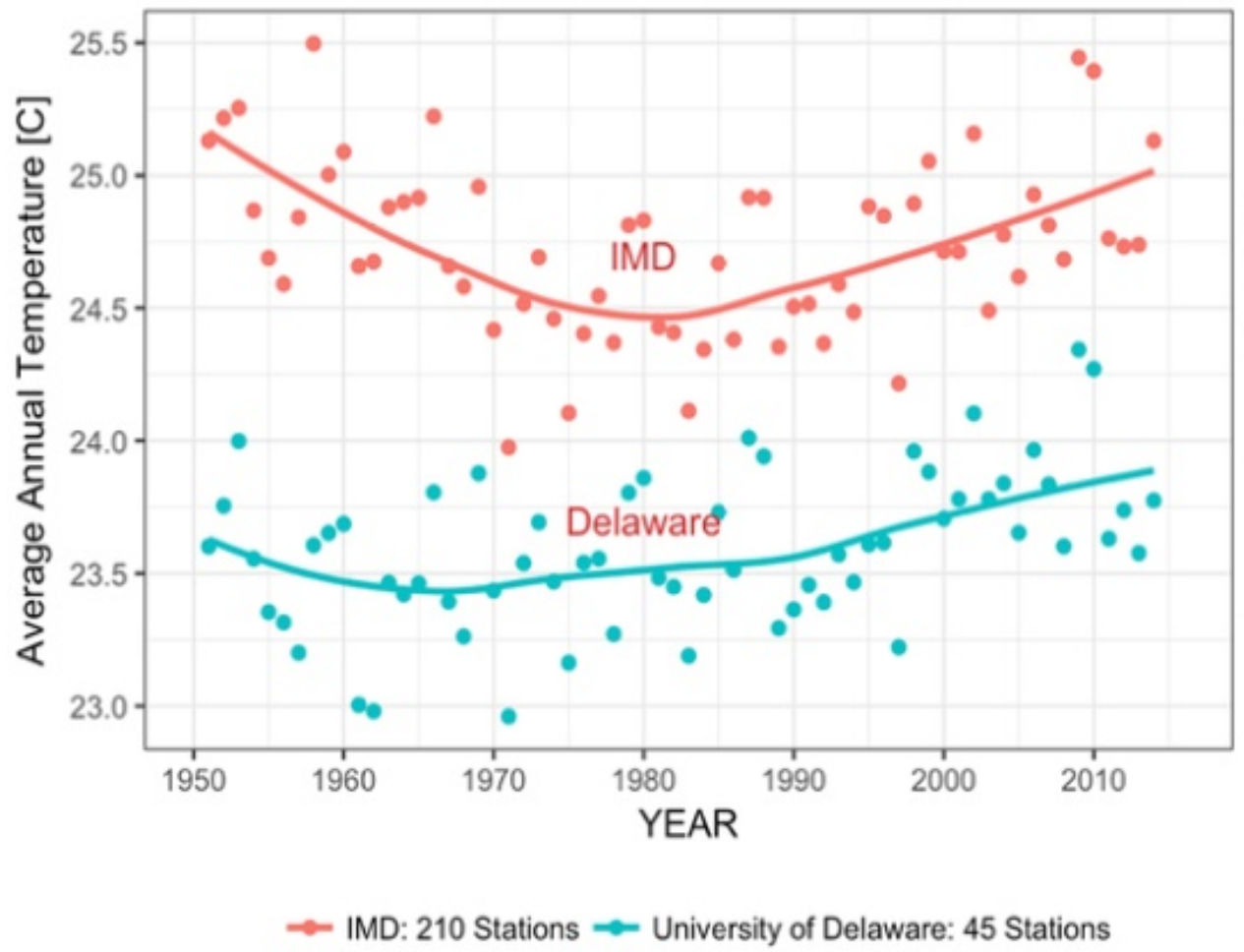

(India, 2018)

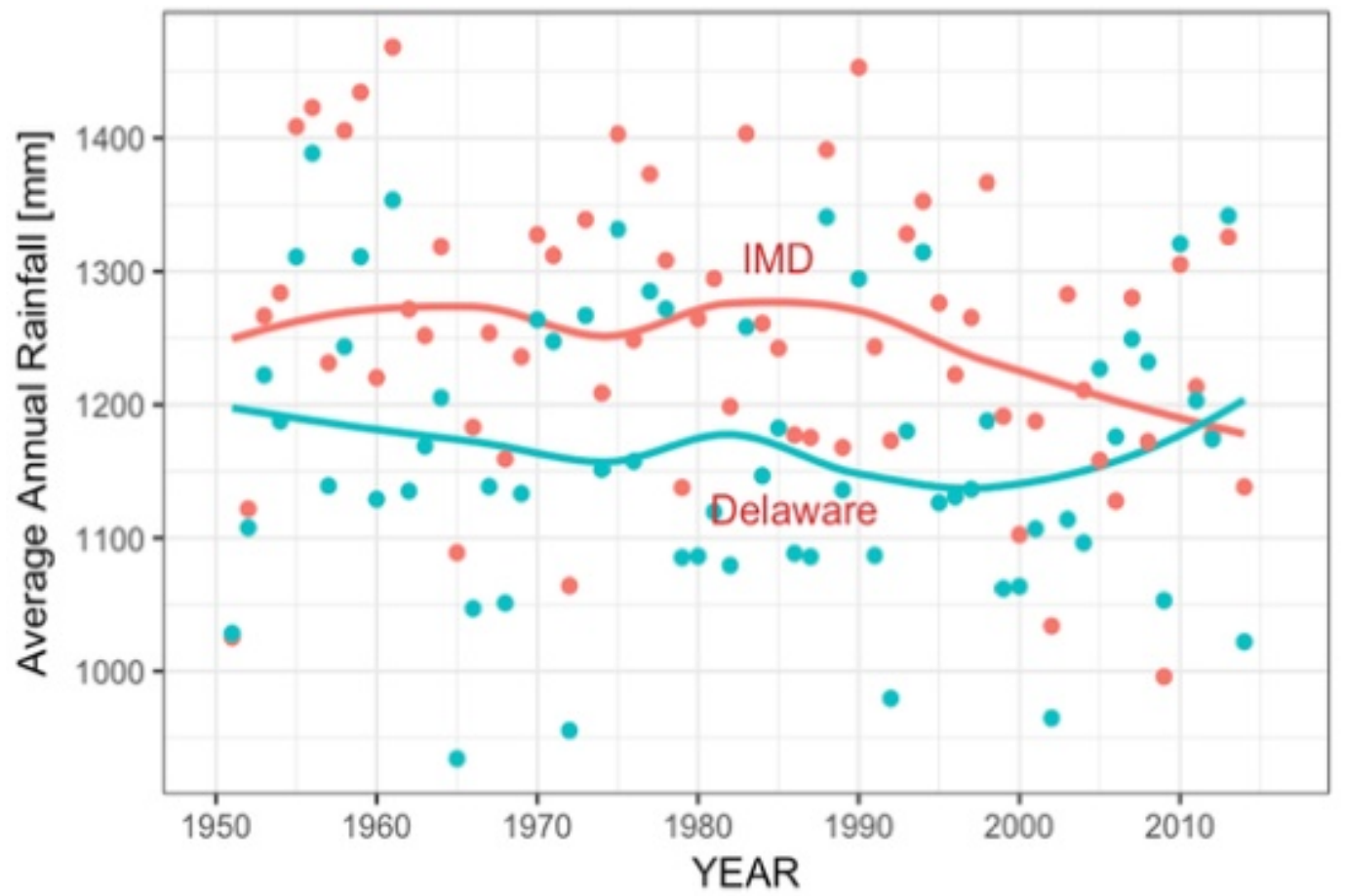

$\leadsto$ IMD: 2140 Stations $\approx$ University of Delaware: 300 Stations

(India, 2018) 
The average annual temperatures in India have increased by approximately 0.48 degrees (just between the year $1970 \&$ 2016), and average rainfall has decreased by $26 \mathrm{~mm}$ (also between $1970 \& 2016$ ). We can also see that there has been a firm surge in extremes of temperature. The occurrence of having 'very hot' days has increased with that of the number of dry days as well. This is constant with various models of weather change which forecast a degree of greater variation in weather patterns.

Next, we will discuss the effects of temperature on the output of irrigated (in green line) and unirrigated (in red line) for areas sowing in two major crop seasons of Kharif and Rabi.

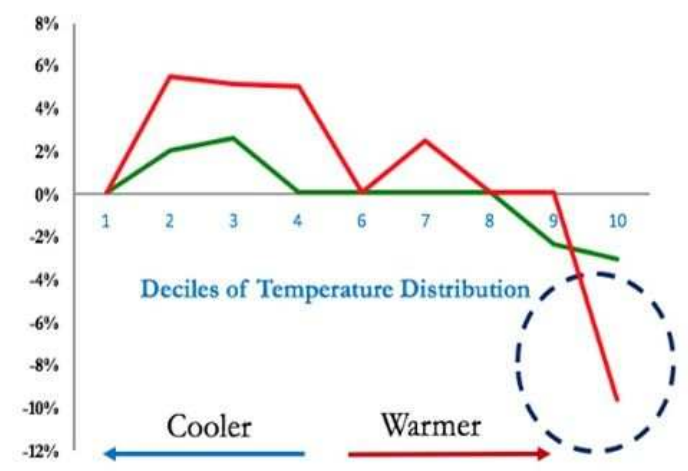

a) For Kharif Crop

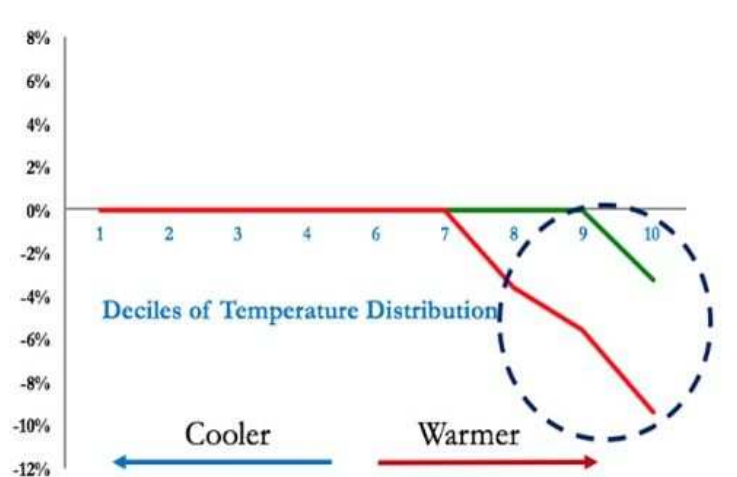

b) For Rabi crop

(India, 2018)

Observed effects of rainfall on production in irrigated (marked in green) and unirrigated (marked in red) areas

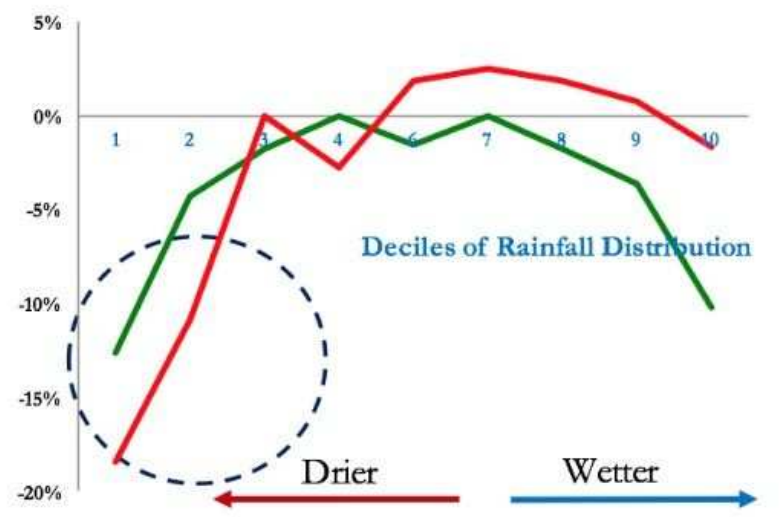

a) For Kharif Crop

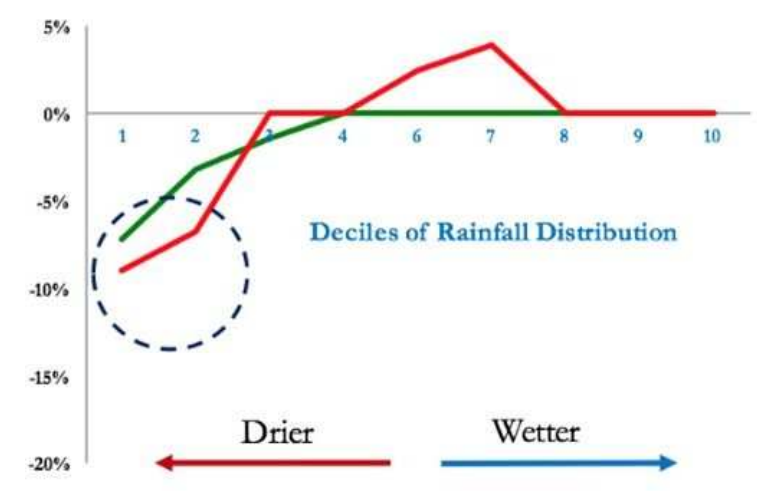

b) For Rabi crop

(India, 2018)

Two findings can be stressed from the graphical illustrations of the above:

- The observed effects of rainfall and temperature on the production of crops are observed to be highly non-linear in nature and always lie in the extremes. For example, shocks that are moderate in nature like rainfall in the 3rd decile or temperature in the 7 th decile have very little effect on crop production output.

- A great variation is observed between those areas having irrigation when compared to unirrigated areas. As we can see, irrigated areas are likely to bear weather shocks. This can also beseenbecause for a majority of instances the green line in all the four graphs lies above the red line. This can also be seen at the extremes of rainfall distribution and temperature. 


\section{TRENDS OF CLIMATE CHANGE IN INDIA - LIVESTOCK PERSPECTIVE}

Livestock farming is an important part of the rural economy of India as many farmers due depending on it either fully or partially for economic support of some kind. The aforementioned change in the climate poses a tough task for the future of livestock farming in the country. The previously discussed rise in temperature in the range of $2-4{ }^{\circ} \mathrm{C}$ for the entire geographical stretch of India will likely increase the moisture content in the air which can further result in increased cases of heat stress incidents in dairy animals. This will hamper milk production activities. With a growing population in the country, the demand for milk and even meat is growing by each passing day. India currently has the 2nd largest number of cattle which is only less than that of Brazil (which has $13 \%$ of the global population) and also the biggest number of buffaloes (56\% of the global population) in the world. (PUBLISHERS, 2017)

Climate change not only poses a threat to agricultural activities but also produces a similar threat to livestock farming as well. This is because climate changeshave their effect on the quality of production of animal fodder, the ready availability of water, reproduction rate of animal and the subsequent production of milk, diseases which are rampant among the livestock and other such critical factors related to livestock farming.

Talking about weather changes, we will discuss what are the major changes which affect livestock production. Like in the case of agriculture the two prime causes are Annual temperature and rainfall, similarly, in case of livestock, four factors are critical:

- Air Temperature

- Relative Humidity

- Air Movement, and

- Solar Radiation

These four factors can greatly influence livestock farming. E.g. dairy cows form a recognizable chunk in the rural livestock agriculture of India. If we talk about dairy cow's reaction to heat stress, we will find that such an incident will promote a reduction in feed intake, increase in water intake, change in metabolic rate, increase in respiration rate, noticeable changes in blood hormone profile and an increase in their body temperature. (PUBLISHERS, 2017)

If we talk about all the probable effects in the livestock farming segment of India in case of Climate change, we can list them down as:

- Great impact on the production of milk

- Observable effect on the rate of animal reproduction

- Impact on meat and egg production in poultry

- Effect on feed and fodder production

- Rampant increase of outbreak of diseases

Thus, we see, that just like agriculture, Livestock farming too will be greatly affected due to climate change in India. 


\section{TRENDS OF CLIMATE CHANGE IN INDIA - OTHER THAN AGRICULTURE \& LIVESTOCK PERSPECTIVE}

While we have covered the challenges of climate change both in agriculture and livestock, there are still other avenues on which the rural economy of India depends upon. These being the production of local handicrafts and service sectors.

The production of local handicrafts in India is predominantly depended upon local raw materials like bamboo for furniture in Assam, Silk, or Cotton for sarees or wood for furniture in Rajasthan. We can see a clear pattern where it is obvious that the Handicraft industry either depends on agriculture activities or natural resources for their raw materials. With an adverse effect on climate, the production of these raw materials will be hampered thus further halting the production of handicrafts. Even if the raw material is available, the supply of it might reduce which can in turn render economies of scale for the artisan out of favor since final buyers might not accept the increased price of goods.

Thus, not only agriculture and livestock farming but local handicraft production will also suffer due to its nature of using allied products from either farming or livestock as raw material.

The one remaining sector of service in the rural economy will be rendered unproductive as services are generally assistive activities for primary production e.g. construction of a shelter for Livestock, labor activities in the harvest season, polishing of wood for furniture, etc. Without proper functioning of agriculture, livestock farming, and handicraft production, the service sector will have very limited scope in the rural economy of India.

\section{SUGGESTIONS}

\section{Current Emphasis Points for Agriculture should be:}

- A clear analysis must be done of climate projections and coming trends. Also, a risk assessment should be done District-wise.

- Metrological data should be monitored from various institutions (both Public \& Private), and interventions must be designed referring to this specific data.

- Valuable Partnerships should be established between departments giving meteorological data, agriculture centers like Central Agriculture Universities, and various Research Institutions to design a complete adaptation plan to mitigate future risks.

- Proper monitoring of project outcomes in connection with weather patterns being observed so that a new kind of knowledge \& experiences is created with community members.

- The proper focus must be ensured on long-term institutional sustainability, as these proposed actions need to be done for the long term.

\section{Current Emphasis Points for Livestock should be:}

- Mitigate risks coming from the effects of changing climate.

- Mitigate risks of potential changes in livestock feeding and their nutrition

- Mitigate risks of potential effects of diseases and parasites 
- To find if Newer breeds of Livestock can be developed or some entirely new animal can be introduced in the changing climate. For E.g. in Climate such as India's, instead of Chicken, Duck farming can prove beneficial in wetter climates.

\section{How can we Achieve this:}

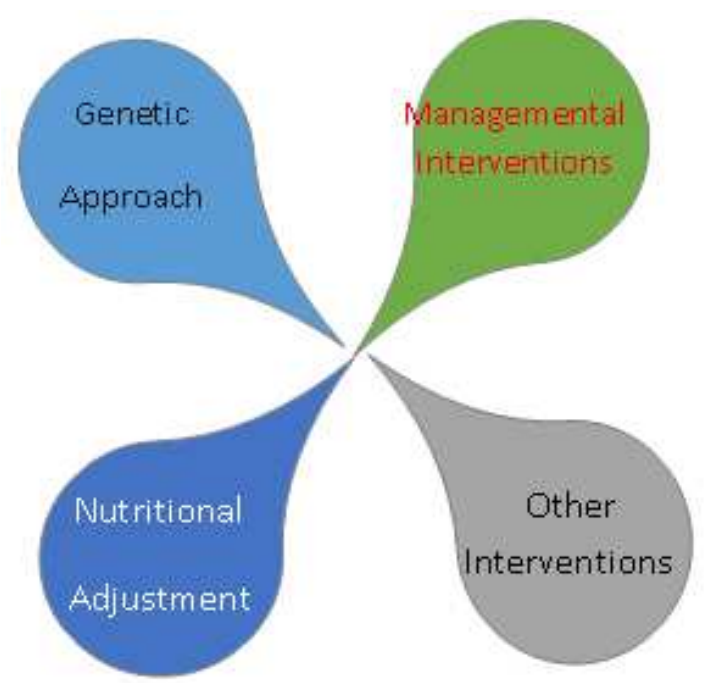

Discussing Livestock Management in Climate Change

\section{Genetic Approach}

- Development of Local breeds which will have adaptive traits for extreme climate, humidity and resistive to diseases

- $\quad$ Providing Strategies for Breeding management to farmers

\section{Nutritional Adjustments}

- Adjusting Animals Diets wherever possible with low resource incentive fodder.

- Exploring the addition of feed additives like mineral supplements to maintain livestock health in new challenging conditions

\section{Management Interventions}

- $\quad$ Planning proper water supply, Stocking density, and provision of livestock roofs.

- Need for regulation in weather like Temperature, Humidity,etc wherever needed.

\section{Other Interventions}

- Need for development of Intensive Fodder production system

- Exploring unconventional resources as feed for the livestock e.g. wasteproducts from the food industry, vegetable waste, brewer's waste grain, etc.

\section{CONCLUSIONS}

A Possible Action Plan which can be developed to mitigate the looming Climate change threat on Indian rural economy 
can be:

As we can see in the above diagram, we must find ways to modify current agriculture practices wherever possible along with also exploring the possibilities to introduce newer variants of crops to increase yield. In the same way, livestock farming practices must also be updated and newer livestock can be considered for rearing ifthey happen to be better suited for the changing climate.

Awareness should be spread in rural areas for climate change so that they can better prepare for the coming crisis whenever it presents itself in the future.

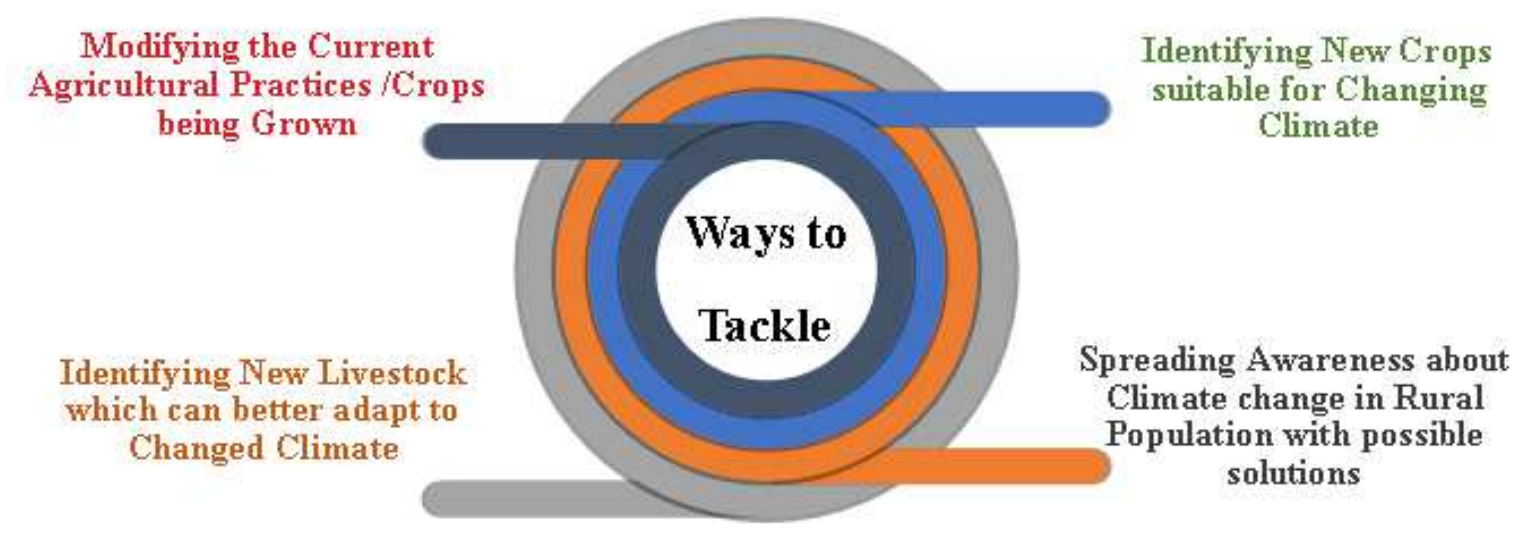

Initiatives currently being done in other countries to address climate change

- Duck Cultivation instead of Chicken is being promoted as the Indian Subcontinent is expected to have a wetter climate and Duck is more suitable in such climate as they are well adapted for living in the water. Chicken are prone to diseases in humid climates and their living conditions need to be heavily monitored round the clock.(Atlantic)

- $\quad$ Rice Farming is being promoted as it will be better suitable for the expected wetter climates which parts of India are expected to have as per the observed changes in the weather pattern.(FAO)

- Awareness is being spread about newer Agricultural practices which are less resource incentive and can mitigate the gradual changes being brought by climate change(Nations)

- Integrating climate change policies into countries legislature to factor in a long-term battle having reform centric agenda (Nations)

- Wide Promotion of clean energy technologies in various regions of the world

- Reducing Emissions from Deforestation and Forest Degradation(Nations)

\section{REFERENCES}

1. Atlantic, T. (n.d.). Retrieved June 25, 2020, from https://www.theatlantic.com/international/archive/2019/07/bangladeshclimate-change-floods-ducks/593581/ 
2. Bank, T. W. (2020, June 29). India: Climate Change Impacts. Retrieved from https://www.worldbank.org/en/news/feature/2013/06/19/india-climate-change-impacts\#: :text=Climate change is expected to, a scenario without climate change.

3. Bineeta, Satpathy, and M. Prusty. "Technological interventions in vegetable production for rural livelihood management in the mid central table land zone of Odisha." International Journal of Agricultural Science and Research (IJASR) 5.4 (2015): 69-74.

4. Connecting the Dots Evolving Practical Strategies for Adaptation to Climate Change. (2013). WOTR. Retrieved June 30, 2020, from https://www.weadapt.org/sites/weadapt.org/files/legacy-new/knowledge-base/files/1471/53ce4b71d2063wotrlivestock-position-paper.pdf

5. Council, N. I. (2009, June 29). Retrieved from https://www.hsdl.org/?view\&did=24137

6. Council, N. I. (2009, May). India: The Impact of CLimate Chnage to 2030 Geopolitical Implications. Retrieved June 30, 2020, from https://www.dni.gov/files/documents/2009 Conference Report_India_The Impact of Climate Change to 2030.pdf

7. FAO, U. (n.d.). Retrieved June 25, 2020, from http://www.fao.org/3/CA3019EN/ca3019en.pdf

8. GlobalCHange.org. (n.d.). Understand Climate CHange. Retrieved June 30, 2020, from https://www.globalchange.gov/climate-change

9. India, I. f. (2018, August 16). Ideas for India. Retrieved from https://www.ideasforindia.in/topics/agriculture/climate-changeand-indian-agriculture.html

10. Kumari, Shanta, and H. R. Sharma. "Farmers' perception on environmental effects of pesticide use, climate change and strategies used in mountain of Western Himalaya." International Journal of Agricultural Science and Research (IJASR) Vol 8 (2018): 57-68.

11. Mekonen, Aregai, and M. V. Chandran. "The long term effects of land uselland cover changes on agriculture and sustainability of livelihood. A case study of Laelay-Koraro, Middle Highland Tigray, Ethiopia." International Journal of Agricultural Science and Research (IJASR) 3.2 (2013): 93-100.

12. M. Melissa Rojas-Downing, A. P. (2017, February 10). Climate change and livestock: Impacts, adaptation, and. Climate Risk Management, 145-163.

13. Mukherjee, M. M. (2017). Global Warming and Climate Change in India: A Social Work Perspective. ePress Publication. Retrieved June 30, 2020, from https://www.unitec.ac.nz/whanake/wp-content/uploads/2018/03/Global-Warming-and-ClimateChange-in-India.pdf

14. Poshan, O. (2020). Actionable Policies To Make Indian Agriculture Climate-Resilient. Retrieved June 30, 2020, from https://poshan.outlookindia.com/story/poshan-news-actionable-policies-to-make-indian-agriculture-climate-resilient/344974

15. PUBLISHERS, C. (2017, August 16). Impact of Climate Change on Livestock, Various. Approaches in Poultry, Dairy \& Veterinary Sciences, 64-70. Retrieved June 30, 2020, from https://crimsonpublishers.com/apdv/pdf/APDV.000517.pdf

16. Ramesh Chand, S. K. (n.d.). Changing Structure of Rural Economy of India. Discussion Paper. Retrieved June 30, 2020, from https://niti.gov.in/writereaddata/files/document_publication/Rural_Economy_DP.pdf

17. Siddharth Hari, P. K. (2018). Climate Change and Indian Agriculture. Retrieved June 30, 2020, from https://www.ideasforindia.in/topics/agriculture/climate-change-and-indian-agriculture.html

18. United Nations - Helping Countries Tackle Climate Change in AsiaPacific

19. https://www.unenvironment.org/regions/asia-and-pacific/regional-initiatives/helping-countries-tackle-climate-change 